\title{
KESIAPAN MENIKAH PADA DEWASA MUDA DAN PENGARUHNYA TERHADAP USIA MENIKAH
}

\author{
Fitri Sari ${ }^{1}$, Euis Sunarti ${ }^{* *}$ \\ ${ }^{1}$ Departemen IImu Keluarga dan Konsumen, Fakultas Ekologi Manusia, Institut Pertanian Bogor, \\ Bogor 16680, Indonesia \\ ${ }^{*}$ E-mail: euisnm@gmail.com
}

\begin{abstract}
Abstrak
Penelitian ini bertujuan untuk menganalisis faktor-faktor kesiapan menikah pada dewasa muda dan menganalisis pengaruhnya terhadap usia menikah. Responden dalam studi ini sebanyak 110 mahasiswa. Data kualitatif kesiapan menikah dianalisis dengan analisis konsep, menghasilkan tujuh faktor kesiapan menikah yaitu kesiapan emosi, sosial, finansial, peran, seksual, spiritual, dan usia. Data kuantitatif kesiapan menikah dianalisis dengan analisis faktor menghasilkan sepuluh faktor yaitu mengelola emosi, empati, keterampilan sosial, kognisi sosial, kesiapan peran, seksual, usia, finansial, kemampuan komunikasi, dan toleransi. Berdasarkan dua analisis tersebut, faktor-faktor kesiapan menikah menurut dewasa muda adalah kesiapan emosi (mengontrol emosi dan kemampuan empati), sosial (keterampilan sosial, kognisi sosial, dan toleransi), peran, kemampuan komunikasi, usia, finansial, dan seksual. Hasil menunjukkan adanya perbedaan kesiapan menikah antara laki-laki dan perempuan. Kesiapan menikah paling penting bagi laki-laki adalah kesiapan finansial dan bagi wanita adalah kesiapan emosi. Usia ideal menikah menurut laki-laki 26,3 tahun dan perempuan 23,9 tahun. Usia ingin menikah laki-laki 26,1 tahun dan perempuan 24,2 tahun. Uji regresi menunjukkan kesiapan menikah memengaruhi usia menikah. Peningkatan kemampuan empati dan kesiapan finansial menyebabkan penambahan usia menikah. Sementara itu, peningkatan kesiapan usia, seksual, dan kemampuan komunikasi berpengaruh terhadap penurunan usia menikah.
\end{abstract}

Kata kunci: dewasa muda, kesiapan menikah, usia menikah

\section{Marriage Readiness among Young Adults and Its Influence on the Marriage Age}

\begin{abstract}
This study aimed to analyze marriage readiness factors among young adults and to analyze its influences on the marriage age. Samples in this study were 110 college students. Qualitative data of marriage readiness was analyzed using content analysis approach, revealed seven factors that are emotional, role, financial, social, age, spiritual, and sexuality readiness. Quantitative data of marriage readiness was analyzed by using analysis factor, and revealed ten factors that are emotional control, empathy ability, financial, role, age, and sexuality readiness, communication skill, social ability, social cognitive, and tolerance. Based on the two analysis, marriage readiness factors among young adults were emotional (emotional control and empathy), social (social ability, social cognitive, and tolerance), role, communication, age, financial, and sexual. Marriage readiness between male dan female was different, for male the most important was financial readiness, but female was emotional readiness. Ideal marriage age for male was 26,3 and for female was 23,9 years old, but expected age to marriage of male was 26,1 and female was 24,2 years old. Statistic regression analysis showed that marriage readiness influence the marriage age. The increasing of empathy ability and financial readiness influenced on increasing age of marriage. Meanwhile, the increasing of age readiness, sexuality, and communication ability influenced on the decreasing of marriage.
\end{abstract}

Keywords: age of marriage, marriage readiness, young adult

\section{PENDAHULUAN}

Penyesuaian terhadap peran dan tugas bagi pasangan yang baru menikah sering menimbulkan masalah. Salah satu penyebab sulitnya menjalankan tugas baru adalah kurangnya kesiapan diri untuk menjalankan tugas tersebut (Hurlock, 1994). Kesiapan menikah menurut Duvall dan Miller (1985) adalah keadaan siap atau bersedia dalam berhubungan dengan pasangan, siap menerima tanggung jawab sebagai suami atau istri, siap terlibat dalam hubungan seksual, siap mengatur keluarga, dan siap mengasuh anak. Menurut Blood (1978), kesiapan menikah terdiri atas kesiapan emosi, kesiapan sosial, kesiapan peran, kesiapan usia, dan kesiapan finansial. Perubahan zaman membuat kesiapan menikah 
menurut pandangan ahli belum tentu sesuai dengan kesiapan menikah yang dibutuhkan calon pasangan pada saat sekarang ini.

Kesiapan menikah diasumsikan akan lebih dipikirkan oleh dewasa muda, karena menikah adalah salah satu tugas perkembangan masa dewasa muda. Erickson (1963) menambahkan bahwa masa dewasa muda merupakan masa keintiman melawan isolasi (intimacy vs isolation). Oleh karenanya, dewasa muda akan lebih memikirkan dan mencari informasi mengenai kesiapan menikah, akan tetapi sumber informasi mengenai kesiapan menikah masih sangat sedikit. Dengan demikian, penelitian mengenai kesiapan menikah masih sangat dibutuhkan. Penelitian ini dilakukan untuk menganalisis faktor kesiapan menikah pada dewasa muda. Penelitian juga dilakukan untuk menganalisis perbedaan kesiapan dan usia menikah berdasarkan jenis kelamin. Selanjutnya, penelitian dilakukan untuk menganalisis pengaruh karakteristik individu, karakteristik keluarga, dan kesiapan menikah terhadap usia menikah pada laki-laki dan perempuan.

\section{METODE}

Lokasi penelitian dengan desain cross sectional ini dipilih secara purposive yaitu Fakultas Ekologi Manusia (FEMA), Institut Pertanian Bogor (IPB). Pengumpulan data primer dilakukan pada bulan Juni tahun 2011. Populasi dalam penelitian ini adalah mahasiswa FEMA IPB tahun ajaran 2007-2009 (angkatan 44, 45, dan 46). Jumlah responden setiap angkatan diambil secara proporsi, dan teknik penarikan responden dari setiap angkatan adalah acak sederhana (simple random sampling). Keseluruhan responden berjumlah 110 orang yang dihitung dengan menggunakan rumus Slovin.

Data primer yang dikumpulkan melalui pengisian kuesioner penelitian. Data terdiri atas karakteristik individu, karakteristik keluarga, usia menikah (usia ideal menikah dan usia ingin menikah), kesiapan menikah, dan persetujuan responden terhadap pernyataan-pernyataan yang dikembangkan dari faktor-faktor kesiapan menikah para ahli.

Karakteristik mahasiswa meliputi jenis kelamin (laki-laki atau perempuan), usia (tahun), uang saku per bulan (Rp/bulan), urutan kelahiran, saudara menikah, status berpacaran, serta kesiapan menikah dan alasannya. Karakteristik keluarga meliputi usia orang tua (tahun), usia orang tua saat menikah (tahun), pekerjaan orang tua, pendapatan orang tua per bulan (Rp/bulan), lama pendidikan (tahun), dan kelengkapan orang tua.

Persepsi mengenai kesiapan menikah diperoleh melalui pertanyaan terbuka (openended question). Responden tidak diberi pilihan jawaban, tetapi menjawab pertanyaan sesuai dengan pendapatnya. Pertanyaan tersebut terdiri atas: (1) arti pernikahan, (2) tujuan ingin menikah, (3) arti kesiapan menikah, (4) kesiapan menikah untuk laki-laki, (5) kesiapan menikah untuk perempuan, (6) tugas istri, (7) tugas suami, (8) usia ideal menikah bagi lakilaki dan perempuan,(9) usia ingin menikah, (10) alasan siap atau tidak siap menikah.

Persetujuan responden terhadap kesiapan menikah menurut pandangan ahli terdiri atas 57 pernyataan dengan pilihan jawaban menggunakan skala Likert, yaitu sangat setuju (5), setuju (4), ragu-ragu (3), tidak setuju (2), dan sangat tidak setuju (1). Pernyataan tersebut dikembangkan dari delapan faktor kesiapan menikah menurut pendapat para ahli, yaitu: (1) kesiapan emosi (Blood, 1978; Goleman, 1997), (2) kesiapan usia (Blood, 1978), (3) kesiapan sosial (Blood, 1978), (4) kesiapan peran (Blood, 1978), (5) kesiapan seksual (Duval \& Miller, 1985), (6) kemampuan berkomunikasi (Duval \& Miller, 1985), (7) kesiapan spiritual (Holman, Bolby, \& Larson, 1994), dan (8) kesiapan finansial (Blood, 1978).

Analisis data menggunakan uji beda $t$, uji regresi linear berganda dengan metode backward, dan analisis faktor. Uji beda $t$ digunakan untuk menganalisis perbedaan variabel penelitian berdasarkan jenis kelamin. Uji regresi linear berganda digunakan untuk menganalisis pengaruh karakteristik individu dan faktor-faktor kesiapan menikah terhadap usia menikah. Analisis faktor pada prinsipnya digunakan untuk mereduksi data, yaitu proses meringkas item-item menjadi faktor yang lebih sedikit dan menamakannya. Analisis faktor digunakan untuk menganalisis 57 pernyataan yang akan direduksi menjadi set atau kelompok atau faktor yang lebih kecil, dan dinamai setiap faktornya. Data yang berasal dari pertanyaan terbuka mengenai kesiapan menikah dilakukan analisis menggunakan pendekatan analisis konsep (content analysis). Analisis konsep yang digunakan didasarkan kepada pola deduktif (umum-khusus) yang mana peneliti sudah memiliki hipotesis yang akan di uji. Tujuan dari analisis konsep adalah untuk menguji kesesuaian faktor-faktor kesiapan menikah menurut para ahli dengan persepsi mahasiswa. 


\section{HASIL}

\section{Karakteristik Mahasiswa dan Keluarga}

Dewasa muda yang menjadi responden dalam penelitian ini terdiri atas 32 orang lakilaki $(29,1 \%)$ dan 78 orang perempuan $(70,9 \%)$. Mahasiswa laki-laki memiliki rentang usia antara 18-24 tahun, sedangkan mahasiswa perempuan 18-23 tahun. Rata-rata usia mahasiswa baik laki-laki maupun perempuan adalah 20 tahun. Rentang uang saku untuk mahasiswa laki-laki adalah Rp350.000,00Rp1.600.000,00 dengan rata-rata sebesar Rp745.000,00. Sementara itu, rentang uang saku untuk mahasiswa perempuan adalah Rp250.000,00-Rp1.500.000,00 dengan ratarata sebesar Rp717.000,00. Selanjutnya, empat dari sepuluh mahasiswa laki-laki $(40,6 \%)$ dan setengah mahasiswa perempuan $(50,0 \%)$ merupakan anak sulung. Selain itu, lebih kurang sepertiga mahasiswa laki laki $(75,0 \%)$ dan mahasiswa perempuan $(78,2 \%)$ tidak memiliki saudara yang sudah menikah.

Kehidupan mahasiswa sebagai dewasa muda tak lepas dari hubungan dengan lawan jenis, atau secara khusus disebut "pacar". Lebih dari setengah mahasiswa laki-laki $(62,5 \%)$ perempuan lebih dari setengahnya $(56,4 \%)$ tidak sedang berpacaran, dan lebih dari seperempatnya $(37,5 \%)$ sedang berpacaran. Hampir seluruh mahasiswa baik laki-laki $(96,8 \%)$ dan perempuan $(92,3 \%)$ merasa tidak siap jika harus menikah dalam waktu dekat. Alasan tidak siap menikah yang paling banyak disebutkan mahasiswa adalah belum siap secara materi dan belum memiliki pekerjaan $(31,9 \%)$. Alasan kedua karena belum siap secara emosi atau mental, dan karena belum lulus kuliah (16,7\%). Sebagian kecil mahasiswa yang siap untuk menikah, mengatakan alasannya karena sudah siap secara emosi, memiliki pendidikan yang cukup, mampu menjalankan peran dalam rumah tangga, orang tua mengizinkan untuk menikah muda, dan sudah memiliki calon pasangan.

Jumlah anggota keluarga dari mahasiswa lakilaki $(59,4 \%)$ dan perempuan $(51,3 \%)$ adalah 5 6 orang dengan rata-rata sebesar 5 orang. Keluarga mahasiswa laki-laki $(87,5 \%)$ dan perempuan $(89,7 \%)$ termasuk dalam keluarga tidak miskin. Penilaian ini berdasarkan perbandingan antara pendapatan keluarga per kapita dengan garis kemiskinan Provinsi Jawa Barat tahun 2010 (>Rp212.000,00).

Usia ayah mahasiswa laki-laki $(81,2 \%)$ dan perempuan $(85,9 \%)$ termasuk dalam kategori usia dewasa madya (41-60 tahun) dengan ratarata usia sebesar 48,6 tahun. Usia ibu responden laki-laki $(96,9 \%)$ dan perempuan $(93,6 \%)$ juga termasuk dalam kategori usia dewasa madya (41-60 tahun) dengan rata-rata usia sebesar 47,3 tahun. Sebagian besar ayah mahasiswa laki-laki $(90,6 \%)$ dan perempuan $(92,3 \%)$ telah menempuh pendidikan formal lebih dari 9 tahun dengan rata-rata sebesar 14,1 tahun. Demikian juga dengan ibu, sebagian besar ibu dari mahasiswa laki-laki $(81,2 \%)$ dan perempuan $(87,2 \%)$ juga telah menempuh pendidikan formal lebih dari 9 tahun dengan rata-rata sebesar 13,1 tahun.

Sebagian besar mahasiswa laki-laki (90,6\%) dan perempuan $(85,9 \%)$ memiliki orang tua yang masih lengkap dan hanya sebagian kecil yang berasal dari keluarga yang orang tuanya sudah bercerai. Rata-rata usia menikah orang tua baik pada mahasiswa laki-laki maupun perempuan sudah sesuai dengan aturan UU No. 1 tahun 1974 pasal 6 tentang perkawinan yaitu usia di atas 19 tahun untuk laki-laki dan usia di atas 16 tahun untuk perempuan. Nilai rata-rata, standar deviasi, dan koefisien uji beda untuk karakteristik individu dan karakteristik keluarga berdasarkan jenis kelamin disajikan pada Tabel 1.

Tabel 1 Nilai rata-rata dan standar deviasi karakteristik individu dan keluarga berdasarkan jenis kelamin

\begin{tabular}{|c|c|c|c|}
\hline \multirow{2}{*}{$\begin{array}{l}\text { Karakteristik } \\
\text { keluarga }\end{array}$} & \multicolumn{2}{|c|}{ Rata-rata \pm standar deviasi } & \multirow{2}{*}{$\begin{array}{c}p- \\
\text { value }\end{array}$} \\
\hline & Laki-laki & Perempuan & \\
\hline Usia (tahun) & $20,8 \pm 1,3$ & $20,6 \pm 1,0$ & 0,480 \\
\hline $\begin{array}{l}\text { Uang saku } \\
\text { (Rp/bulan) }\end{array}$ & $\begin{array}{c}745.000 \pm \\
338.487\end{array}$ & $\begin{array}{c}717.000 \pm \\
246.879\end{array}$ & 0,670 \\
\hline $\begin{array}{l}\text { Besar } \\
\text { keluarga } \\
\text { (orang) }\end{array}$ & $5,0 \pm 1,3$ & $4,9 \pm 1,2$ & 0,790 \\
\hline $\begin{array}{l}\text { Pendapatan } \\
\text { per kapita } \\
\text { (Rp/bulan) }\end{array}$ & $\begin{array}{c}769.000,0 \pm \\
483.430,5\end{array}$ & $\begin{array}{c}710.000,0 \pm \\
412.189,2\end{array}$ & 0,540 \\
\hline $\begin{array}{l}\text { Usia Ayah } \\
\text { (tahun) }\end{array}$ & $51,8 \pm 6,0$ & $51,4 \pm 5,5$ & 0,710 \\
\hline $\begin{array}{l}\text { Usia Ibu } \\
\text { (tahun) }\end{array}$ & $48,6 \pm 4,8$ & $47,3 \pm 4,4$ & 0,170 \\
\hline $\begin{array}{l}\text { Lama } \\
\text { pendidikan } \\
\text { ayah (tahun) }\end{array}$ & $14,0 \pm 3,5$ & $14,1 \pm 3,1$ & 0,930 \\
\hline $\begin{array}{l}\text { Lama } \\
\text { pendidikan } \\
\text { ibu (tahun) }\end{array}$ & $13,3 \pm 3,9$ & $13,0 \pm 2,9$ & 0,640 \\
\hline $\begin{array}{l}\text { Usia } \\
\text { menikah } \\
\text { ayah (tahun) }\end{array}$ & $26,5 \pm 4,1$ & $26,9 \pm 4,3$ & 0,660 \\
\hline $\begin{array}{l}\text { Usia } \\
\text { menikah ibu } \\
\text { (tahun) }\end{array}$ & $22,8 \pm 3,7$ & $22,6 \pm 3,2$ & 0,830 \\
\hline
\end{tabular}




\section{Kesiapan Menikah}

Hasil jawaban dimensi kesiapan dimasukkan dalam 21 kategori yang mana enam kategori jawaban yang terbanyak disajikan pada Tabel 2. Hasil penelitian menunjukkan bahwa lebih dari tiga perempat mahasiswa laki-laki $(78,1 \%)$ dan tiga perempat mahasiswa perempuan $(75,6 \%)$ merasa bahwa kesiapan menikah artinya siap secara psikologis, mental, atau emosi. Tabel 3 juga menunjukkan bahwa dimensi kesiapan menikah yang secara ratarata menjadi aspek penting bagi mahasiswa yang telah memasuki usia dewasa muda adalah kesiapan fisik dan kesehatan serta kesiapan materi. Selain itu, hasil yang disajikan pada Tabel 3 juga menunjukkan bahwa kurang dari seperlima mahasiswa dewasa muda yang mengidentifikasikan kesiapan menikah sebagai kesiapan menjalan peran, kesiapan bertanggung jawab, maupun kesiapan akan pengetahuan agama dan keimanan.

Selanjutnya, 21 faktor-faktor sebagai dimensi kesiapan menikah berdasarkan jawaban mahasiswa dikonfirmasi dengan ahli sehingga menghasilkan tujuh dimensi utama dari kesiapan menikah yaitu kesiapan emosi, kesiapan sosial, kesiapan peran, kesiapan finansial, kesiapan spiritual, kesiapan seksual, dan kematangan usia. Faktor yang tidak terkonfirmasi adalah kemampuan komunikasi (Tabel 3).

Tabel 2 Sebaran persentase mahasiswa berdasarkan dimensi kesiapan menikah

\begin{tabular}{lcccc}
\hline $\begin{array}{l}\text { Dimensi } \\
\text { kesiapan } \\
\text { menikah }\end{array}$ & $\begin{array}{c}\text { Laki- } \\
\text { laki }\end{array}$ & $\begin{array}{c}\text { Perempu- } \\
\text { an }\end{array}$ & $\begin{array}{c}\text { Rata- } \\
\text { rata } \\
\text { total }\end{array}$ & Jawaban \\
\hline $\begin{array}{l}\text { Kesiapan } \\
\text { psikologis/ } \\
\text { mental/ }\end{array}$ & 78,1 & 75,6 & 76,4 & 26,2 \\
emosi & & & & \\
$\begin{array}{l}\text { Kesiapan } \\
\text { fisik dan }\end{array}$ & 40,6 & 61,5 & 55,4 & 19,0 \\
kesehatan & & & & \\
$\begin{array}{l}\text { Kesiapan } \\
\text { materi }\end{array}$ & 65,6 & 43,6 & 50,0 & 17,2 \\
$\begin{array}{l}\text { Kesiapan } \\
\text { menjalan- }\end{array}$ & 15,6 & 21,8 & 14,5 & 6,2 \\
kan peran & & & & \\
$\begin{array}{l}\text { Kesiapan } \\
\text { bertanggung }\end{array}$ & 12,5 & 12,8 & 12,7 & 4,4 \\
jawab & & & & \\
$\begin{array}{l}\text { Pengetahu- } \\
\text { an agama } \\
\text { dan } \\
\text { keimanan }\end{array}$ & 9,4 & 11,5 & 10,9 & 3,7 \\
\hline
\end{tabular}

Tabel 3 Pemetaan kesiapan menikah mahasiswa ke dalam faktor-faktor kesiapan menikah menurut ahli

Definisi kesiapan menikah responden
Faktor kesiapan menikah menurut ahli

1. Kesiapan psikologis/mental/emosi/ batin

2. Siap berkomitmen

3. Siap menghadapi dan memecahkan masalah

Kesiapan emosi

4. Kedewasaan

5. Kesiapan menerima kekurangan orang lain

6. Kesiapan mencintai

1. Kemampuan beradatasi dengan lingkungan

2. Kesiapan membangun hubungan sosial

3. Kemandirian

1. Kesiapan menjalankan peran

2. Pengetahuan tentang pernikahan dan pengasuhan

Kesiapan peran

3. Kemampuan merencanakan masa depan

4. Bertanggung jawab

1. Pekerjaan atau penghasilan

2. Memiliki tabungan

Kesiapan finansial

3. Materi

1. Pengetahuan agama dan keimanan

Kesiapan sosial

$x^{2}$

2. Kesiapan fisik dan

kesehatan

3. Kesiapan organ reproduksi (seksual)

\begin{tabular}{cl}
\hline 4. Kematangan usia & Kematangan usia \\
\hline- & $\begin{array}{l}\text { Kemampuan } \\
\text { berkomunikasi }\end{array}$ \\
\hline
\end{tabular}

Perbedaan Kesiapan Menikah Menurut Jenis Kelamin

Menurut keseluruhan mahasiswa faktor kesiapan menikah laki-laki urutannya adalah kesiapan finansial, kesiapan emosi, kesiapan peran, kesiapan fisik yang sehat, kesiapan spiritual, kesiapan sosial, kesiapan seksual, dan kesiapan usia. Menurut keseluruhan mahasiswa, faktor kesiapan menikah yang penting bagi perempuan adalah kesiapan emosi, kesiapan peran, kesiapan finansial, kesiapan fisik, kesiapan seksual, kesiapan spiritual, kesiapan sosial, dan kesiapan usia. Urutan faktor kesiapan menikah disajikan pada Tabel 4. 
Tabel 4 Sebaran mahasiswa berdasarkan jenis kelamin yang menyebutkan urutan faktor kesiapan menikah

\begin{tabular}{lrr}
\hline $\begin{array}{c}\text { Faktor kesiapan } \\
\text { menikah }\end{array}$ & $\begin{array}{c}\text { Laki-laki } \\
(\%)\end{array}$ & $\begin{array}{r}\text { Perempuan } \\
(\%)\end{array}$ \\
\hline Kesiapan finansial & 100,0 & 45,4 \\
Kesiapan emosi & 85,4 & 84,5 \\
Kesiapan peran & 62,8 & 53,6 \\
Kesiapan fisik (sehat) & 29,1 & 29,1 \\
Kesiapan spiritual & 28,2 & 20,9 \\
Kesiapan sosial & 12,7 & 17,3 \\
Kesiapan seksual & 7,3 & 25,4 \\
Kesiapan usia & 1,8 & 1,8 \\
Kemampuan & 0,0 & 0,0 \\
komunikasi & & \\
\hline
\end{tabular}

Identifikasi faktor kesiapan menikah selanjutnya menggunakan uji analisis faktor yang digunakan untuk mereduksi 57 pernyataan kedalam set atau kelompok atau faktor yang lebih kecil, dan dinamai setiap faktornya. Analisis faktor yang pertama menghasilkan 14 faktor dengan total kumulatif 71,1 persen. Faktor tersebut adalah mengelola emosi (6 item), empati (5 item), keterampilan sosial (5 item), kesiapan usia (4 item), kesiapan finansial (5 item), kesiapan seksual (4 item), komunikasi (3 item), kesiapan peran (3 item), kognisi sosial (3 item), toleransi (2 item), keagamaan ( 1 item), self-esteem (1 item), tidak egois (1 item), dan berfikir positif (1 item). Nilai ini menunjukkan bahwa total keragaman atau informasi yang dapat digali dari empat belas faktor yang terbentuk adalah sebesar 71,1 persen, namun terdapat 4 faktor terbawah yang hanya memiliki satu pernyataan. Jika hanya ada satu pernyataan pada satu faktor dan kemudian tidak valid maka faktor tidak bisa diuji lanjut, sehingga keempat faktor tersebut dianggap tidak valid.

Analisis faktor yang kedua akhirnya dilakukan, dengan jumlah faktor ditentukan sendiri yaitu 10 faktor dan 8 faktor. Jumlah pernyataan yang tersiolasi menjadi lebih kecil yaitu 36 pernyataan. Akan tetapi total kumulatif 10 faktor lebih banyak memberikan informasi daripada 8 faktor. Faktor (10) terdiri atas mengelola emosi (6 item), kesiapan peran (3 item), empati (5 item), kesiapan usia (4 item), komunikasi (3 item), keterampilan sosial (4 item), kesiapan seksual (4 item), kesiapan finansial (3 item), kognisi sosial, (2 item), dan toleransi (2 item). Total pernyataan berjumlah 36 dan total kumulatif sebesar 62,3 . Faktor (8) terdiri atas mengelola emosi (6 item), empati \& komunikasi (8 item), kesiapan peran (4 item), kesiapan usia (4 item), kesiapan finansial (5 item), kesiapan seksual (4 item), keterampilan sosial (3 item), dan kognisi sosial (2 item). Total pernyataan berjumlah 36 dan total kumulatif sebesar 56,6.

Penamaan 10 faktor berdasarkan pernyataan yang diwakilinya. Faktor pertama terdiri atas pernyataan tidak suka membesarkan masalah yang kecil, tidak pendendam, tidak melampiaskan amarahnya ke orang terdekat, tahu kelebihan dan kekurangan, tidak mengeluarkan kata-kata kasar ketika marah, dan tidak minum-minuman beralkohol, diberi nama "mengelola emosi". Faktor kedua terdiri atas pernyataan mengetahui apa yang dibutuhkan orang lain, bersedia berkorban untuk orang lain, mengetahui alasan penyebab timbulnya perasaan, mampu membedakan perasaan yang dirasakan, dan tidak memotong pembicaraan orang lain, sehingga diberi nama "kemampuan empati". Faktor ketiga terdiri atas pernyataan bisa bekerja dalam tim, mudah bergaul dengan teman sebaya, senang mengikuti kegiatan masyarakat, berusaha menyelesaikan masalah dengan sabar, dan mampu menyelesaikan masalah dengan orang lain, faktor ini dinamai "ketrampilan sosial".

Faktor keempat terdiri atas pernyataan yang berhubungan dengan usia menikah sehingga diberi nama "kesiapan usia". Faktor kelima terdiri atas pernyataan memiliki pekerjaan, tidak merokok, memiliki tabungan untuk masa depan, mencari informasi cara berumah tangga, dan memiliki tempat tinggal yang terpisah dari orang tua, sehingga dinamai "kesiapan finansial". Faktor keenam dinamai "kesiapan seksual" karena terdiri atas pernyataan wanita sudah mampu hamil, laki-laki sudah mampu membuahi, siap berhubungan seksual, dan hubungan seksual penting dalam pernikahan. Faktor ketujuh terdiri atas pernyataan pendengar yang baik, memberikan respon positif ketika berkomunikasi, dan mengkritik seseorang dengan cara yang baik, sehingga dinamai dengan "kemampuan komunikasi". Faktor kedelapan terdiri atas pernyataan tahu tugas dan peran suami, tahu tugas dan peran istri, dan mampu mengambil keputusan, dinamai faktor "kesiapan peran".

Faktor kesembilan terdiri atas memiliki pengalaman hidup sendiri, siap tinggal dengan keluarga pasangan, dan memiliki figur pernikahan yang bisa ditiru, faktor ini dinamai "kognisi sosial". Goleman (2007) menyatakan bahwa kognisi sosial adalah pengetahuan dan kemampuan menganalisis bagaimana dunia sosial bekerja serta mengetahui apa yang diharapkan dalam kebanyakan situasi sosial. 


\section{Usia Menikah}

Usia ideal menikah. Rata-rata usia ideal menikah bagi laki-laki menurut mahasiswa lakilaki dan perempuan adalah 26,3 tahun dengan kisaran 23-30 tahun, sedangkan rata-rata usia ideal menikah perempuan menurut mahasiswa laki-laki adalah 23,7 tahun dan menurut mahasiswa perempuan adalah 23,9 tahun dengan kisaran 20-27 tahun. Usia ideal menikah bagi laki-laki menurut lebih dari setengah mahasiswa $(59,1 \%)$ berada pada 26 28 tahun, sedangkan usia menikah ideal bagi perempuan menurut lebih dari setengah mahasiswa $(81,8 \%)$ adalah $23-25$ tahun. Uji statistik menunjukan tidak terdapat perbedaan usia ideal menikah berdasarkan jenis kelamin $(p>0,05)$. Sebaran usia ideal menikah mahasiswa laki-laki dan perempuan disajikan pada Tabel 5.

Usia ingin menikah. Berdasarkan jawaban mahasiswa dalam penelitian ini, ratarata usia ingin menikah adalah 26,1 tahun. Hasil menunjukkan bahwa lebih dari separuh mahasiswa laki-laki $(53,1 \%)$ ingin menikah pada usia 26-28 tahun, hampir separuhnya $(43,5 \%)$ memilih menikah pada usia 23-25 tahun, dan sebagian kecil mahasiswa laki-laki $(3,1 \%)$ ingin menikah pada usia $29-31$ tahun. Pada mahasiswa perempuan rentang usia ingin menikah adalah 22-28 tahun. Hampir seluruh mahasiswa perempuan $(84,6 \%)$ ingin menikah pada usia 23-25 tahun, dan sebagian kecil mahasiswa perempuan $(10,3 \%)$ yang ingin menikah pada usia $26-28$ tahun, $(3,6 \%)$ ingin menikah pada usia 20-22 tahun. Rata-rata usia ingin menikah mahasiswa perempuan adalah 24,24 tahun.

Rata-rata usia ideal menikah laki-laki lebih tinggi dari rata-rata usia ingin menikah mahasiswa laki-laki. Pada mahasiswa perempuan, rata-rata usia ideal lebih rendah daripada usia ingin menikah. Hasil uji beda menunjukkan bahwa terdapat perbedaan antara usia ideal menikah dengan usia ingin menikah, bahkan nilai signifikansi uji beda menunjukkan angka 0,000 ( $p<0,01)$.

Tabel 5 Sebaran usia ideal menikah mahasiswa berdasarkan jenis kelamin

\begin{tabular}{crrrrrr}
\hline \multirow{2}{*}{$\begin{array}{c}\text { Usia } \\
\text { (tahun) }\end{array}$} & \multicolumn{3}{c}{ Laki-laki (\%) } & \multicolumn{3}{c}{ Perempuan(\%) } \\
\cline { 2 - 6 } & \multicolumn{1}{c}{2} & Total & \multicolumn{1}{c}{1} & \multicolumn{1}{c}{2} & Total \\
\hline $20-22$ & 0,0 & 0,0 & 0,0 & 25,0 & 8,9 & 13,6 \\
$23-25$ & 40,6 & 38,5 & 39,1 & 65,6 & 88,5 & 81,8 \\
$26-28$ & 56,2 & 60,3 & 59,1 & 9,4 & 2,6 & 4,5 \\
$29-31$ & 3,1 & 1,3 & 1,8 & 0,0 & 0,0 & 0,0 \\
\hline Keterangan: 1: Usia ideal menikah untuk laki-laki \\
& 2: Usia ideal menikah untuk perempuan
\end{tabular}

\section{Pengaruh Karakteristik Mahasiswa, Karakteristik Keluarga, dan Kesiapan Menikah terhadap Usia Menikah}

Uji pengaruh faktor-faktor kesiapan yang memengaruhi usia menikah menggunakan beberapa model untuk mengetahui model terbaik yang mampu menjelaskan usia menikah. Model yang dipilih adalah yang mampu memberikan informasi paling memadai mengenai usia menikah yang nilai Adjusted $R$ Square lebih dari 0,50. Berdasarkan uji regresi yang telah dilakukan terpilih tiga model yang paling baik untuk menjelaskan mengenai kesiapan menikah.

Pengaruh karakteristik mahasiswa, karakteristik keluarga, dan faktor kesiapan menikah terhadap usia ingin menikah seluruh mahasiswa. Model regresi yang disusun memiliki nilai Adjusted $R$ Square sebesar 0,53. Angka tersebut artinya sebesar 53 persen usia ingin menikah mahasiswa dapat dijelaskan dengan menggunakan variabel yang berpengaruh yang telah disebutkan dalam model, sedangkan sisanya yaitu 47 persen dipengaruhi oleh variabel bebas lain yang tidak ada dalam model tersebut. Hasil analisis pengaruh kesiapan menikah, karakteristik mahasiswa, dan karakteristik keluarga disajikan pada Tabel 6.

Tabel 6 Koefisien regresi untuk analisis pengaruh faktor kesiapan menikah, karakteristik mahasiswa, dan karakteristik keluarga terhadap usia ingin menikah mahasiswa

\begin{tabular}{lcc}
\hline \multicolumn{1}{c}{ Variabel Bebas } & $\beta$ & Sig. \\
\hline Kemampuan empati & 0,179 & $0,030^{*}$ \\
Kesiapan usia & $-0,211$ & $0,004^{*}$ \\
Keterampilan sosial & $-0,116$ & 0,144 \\
Kesiapan seksual & $-0,185$ & $0,014^{*}$ \\
Kesiapan finansial & 0,178 & $0,021^{*}$ \\
Jenis kelamin & 0,668 & $0,000^{*}$ \\
Uang saku & 0,204 & $0,006^{*}$ \\
Urutan anak & $-0,122$ & 0,082 \\
(1=pertama, 0=tidak) & & \\
Status pacar (1=ada, & $-0,149$ & $0,036^{*}$ \\
0=tidak ada) & $-0,108$ & 0,195 \\
Usia nikah ayah & $-0,227$ & $0,009^{*}$ \\
Lama pendidikan ayah & 0,133 & 0,137 \\
Usia menikah ibu & 0,276 & $0,007^{*}$ \\
Lama pendidikan ibu & $-0,184$ & $0,018^{*}$ \\
Pekerjaan ibu (1=kerja, & \multicolumn{2}{c}{0,00} \\
0=tidak bekerja) & \multicolumn{2}{c}{0,59} \\
\hline Sig & \multicolumn{2}{c}{0,53} \\
R ${ }^{\text {Adjusted } R \text { Square }}$ & & \\
\hline Keterangan: *signifikan pada $p<0,05$ &
\end{tabular}


Hasil yang telah disajikan pada Tabel 7 menunjukkan bahwa usia ingin menikah mahasiswa dipengaruhi secara signifikan oleh kemampuan empati, kesiapan usia, keseksual, kesiapan finansial, jenis kelamin, uang saku, status pacar, lama pendidikan ayah, lama pendidikan ibu, dan pekerjaan ibu. Kemampuan empati dan kesiapan finansial berpengaruh signifikan potif terhadap usia ingin menikah. Hasil ini menunjukkan bahwa peningkatan pada kemampuan empati dan kesiapan finansial maka memengaruhi peningkatan mahasiswa menikah di usia tua. Sementara itu, kesiapan usia dan kesiapan seksual berpengaruh signifikan negatif terhadap usia ingin menikah mahasiswa. Hasil ini menunjukkan bahwa peningkatan pada kesiapan usia dan kesiapan seksual berpengaruh pada peningkatan mahasiswa menikah di usia muda.

Jenis kelamin yang berpengaruh signifikan positif terhadap usia ingin menikah menunjukkan bahwa usia ingin menikah lakilaki lebih tua dari perempuan. Demikian juga halnya dengan uang saku. Penambahan jumlah uang saku membuat usia ingin menikah menjadi semakin tua. Selanjutnya, status pacar berpengaruh signifikan negatif dengan usia ingin menikah. Mahasiswa yang memiliki pacar memiliki usia ingin menikah lebih muda dibandingkan yang tidak memiliki pacar. Pendidikan orang tua baik ayah dan ibu juga berpengaruh positif terhadap usia ingin menikah. Penambahan lama ayah dan ibu dalam mengikuti pendidikan formal membuat usia ingin menikah mahasiswa semakin tua. Usia ingin menikah juga dipengaruhi oleh pekerjaan ibu. Mahasiswa yang ibunya bekerja memiliki usia ingin menikah lebih muda dibandingkan mahasiswa yang ibunya tidak bekerja.

Pengaruh karakteristik mahasiswa, karakteristik keluarga, dan faktor kesiapan menikah terhadap usia ingin menikah lakilaki. Model memiliki nilai Adjusted $R$ Square yang cukup baik yaitu 0,57 , artinya usia ingin menikah laki-laki dapat dijelaskan oleh model sebesar 57 persen (Tabel 7). Peningkatan pada kemampuan komunikasi, kesiapan finansial, dan uang saku mahasiswa dapat berpengaruh pada peningkatan mahasiswa laki-laki yang menikah di usia tua. Banyaknya jumlah anggota keluarga akan memengaruhi mahasiswa lakilaki menikah di usia muda. Mahasiswa laki-laki merupakan anak pertama memiliki usia ingin menikah lebih muda dibandingkan yang bukan anak pertama, mahasiswa laki-laki yang berasal dari keluarga miskin memiliki usia menikah yang lebih tua.
Tabel 7 Koefisien regresi untuk analisis pengaruh karakteristik mahasiswa, karakteristik keluarga, dan faktorfaktor kesiapan menikah terhadap usia ingin menikah laki-laki

\begin{tabular}{lcc}
\hline \multicolumn{1}{c}{ Variabel Bebas } & B & Sig. \\
\hline Kemampuan empati & $-0,361$ & 0,171 \\
Kesiapan usia & $-0,284$ & 0,105 \\
Kemampuan komunikasi & 0,590 & $0,036^{*}$ \\
Kesiapan seksual & $-0,308$ & 0,134 \\
Kesiapan finansial & 0,356 & $0,058^{*}$ \\
Kognisi sosial & 0,213 & 0,297 \\
Uang saku & 0,360 & $0,027^{*}$ \\
Urutan anak & $-0,452$ & $0,015^{*}$ \\
(1=pertama,0=bukan & & \\
pertama) & & \\
Jumlah anggota keluarga & $-0,439$ & $0,030^{*}$ \\
Status pacar (1=ada, & $-0,219$ & 0,183 \\
0=tidak ada) & & \\
Usia menikah ayah & $-0,328$ & 0,089 \\
Usia menikah ibu & 0,299 & 0,106 \\
Lama pendidikan ibu & 0,263 & 0,108 \\
Pendapatan per kapita & $-0,541$ & $0,006^{*}$ \\
(1=tidak miskin, 0=miskin) & \multicolumn{2}{c}{0,155} \\
Orang tua (1=lengkap, & 0,245 \\
0=tidak lengkap) & \multicolumn{2}{c}{0,01} \\
\hline Sig & \multicolumn{2}{c}{0,77} \\
$R^{2}$ & \multicolumn{2}{c}{0,57} \\
Adjusted $R$ Square & Keterangan: *signifikan pada $p<0,05$
\end{tabular}

Pengaruh karakteristik mahasiswa, karakteristik keluarga, dan faktor kesiapan menikah terhadap usia ingin menikah perempuan. Model yang disusun untuk menganalisis pengaruh karakteristik mahasiswa, karakteristik keluarga, dan faktor-faktor kesiapan menikah terhadap usia ingin menikah perempuan disajikan pada Tabel 8. Faktor kesiapan menikah yang memengaruhi usia ingin menikah mahasiswa perempuan adalah mengelola emosi, semakin tinggi maka usia ingin menikah semakin tua. Peningkatan kesiapan usia dan kemampuan komunikasi memengaruhi peningkatan pada mahasiswa yang menikah di usia muda. Uang saku yang besar dan pendidikan ibu yang tinggi berpengaruh pada mahasiswa perempuan yang menikah di usia tua, tetapi tingginya pendidikan ayah berpengaruh pada mahasiswa perempuan yang menikah di usia muda. Mahasiswa perempuan yang memiliki pacar, memiliki usia ingin menikah lebih rendah. Mahasiswa yang ibunya bekerja ingin menikah lebih cepat. Mahasiswa perempuan yang berasal dari keluarga miskin ingin menikah lebih muda. Perempuan dengan orang tua yang tidak lengkap ingin menikah lebih tua dibandingkan yang orang tuanya lengkap. 
Tabel 8 Koefisien regresi untuk analisis pengaruh karakteristik mahasiswa, karakteristik keluarga, dan faktorfaktor kesiapan menikah terhadap usia ingin menikah perempuan

\begin{tabular}{|c|c|c|}
\hline Variabel Bebas & ß & Sig \\
\hline Mengelola emosi & 0,271 & $0,022^{*}$ \\
\hline Kemampuan empati & 0,168 & 0,122 \\
\hline Kesiapan usia & $-0,194$ & $0,056^{*}$ \\
\hline Kemampuan komunikasi & $-0,268$ & $0,030^{*}$ \\
\hline Kesiapan seksual & $-0,149$ & 0,131 \\
\hline Uang saku & 0,356 & $0,001^{*}$ \\
\hline $\begin{array}{l}\text { Status pacar (1=ada, } \\
0=\text { tidak ada) }\end{array}$ & $-0,250$ & $0,009^{*}$ \\
\hline Usia menikah ayah & $-0,141$ & 0,166 \\
\hline Lama pendidikan ayah & $-0,438$ & $0,000^{*}$ \\
\hline $\begin{array}{l}\text { Pekerjaan ayah }(1=\text { kerja, } \\
0=\text { tidak bekerja) }\end{array}$ & $-0,142$ & 0,191 \\
\hline Lama pendidikan ibu & 0,509 & $0,000^{*}$ \\
\hline $\begin{array}{l}\text { Pekerjaan ibu ( } 1=\text { kerja, } \\
0=\text { tidak bekerja) }\end{array}$ & $-0,463$ & $0,000^{*}$ \\
\hline $\begin{array}{l}\text { Pendapatan per kapita } \\
\text { (1=tidak miskin, } 0=\text { miskin) }\end{array}$ & 0,273 & $0,014^{*}$ \\
\hline $\begin{array}{l}\text { Orang tua ( } 1=\text { lengkap, } \\
0=\text { tidak lengkap) }\end{array}$ & $-0,275$ & $0,023^{*}$ \\
\hline Sig & \multicolumn{2}{|c|}{0,00} \\
\hline$R^{2}$ & \multicolumn{2}{|c|}{0,54} \\
\hline Adjusted R Square & \multicolumn{2}{|c|}{0,44} \\
\hline
\end{tabular}

\section{PEMBAHASAN}

Kesiapan menikah hasil identifikasi dari jawaban mahasiswa mampu mengidentifikasi tujuh dari delapan faktor kesiapan menikah, yaitu kesiapan emosi, kesiapan sosial, kesiapan seksual, kesiapan peran, kesiapan usia, kesiapan finansial, dan kesiapan spiritual. Faktor yang sama sekali tidak disebutkan adalah kemampuan berkomunikasi, padahal kemampuan komunikasi penting dimiliki sebagai salah satu kesiapan menikah, seringkali suami istri terlibat pertengkaran karena kesalahan dalam komunikasi.

Faktor kesiapan emosi lebih penting dimiliki oleh perempuan. Perempuan umumnya memiliki kemampuan membaca sinyal emosi verbal dan nonverbal yang lebih baik dari pada laki-laki, dan lebih mahir dalam mengungkapkan perasaannya, akibatnya secara rata-rata perempuan lebih mudah berempati dari pada laki-laki (Goleman 1997). Faktor kesiapan finansial, lebih penting dipersiapkan oleh lakilaki terkait dengan tugas suami sebagai pemimpin keluarga yang bertanggung jawab memenuhi kebutuhan anggota keluarganya. Kesiapan finansial juga penting bagi perempuan. Responden kesiapan finansial bagi perempuan adalah memiliki pekerjaan untuk membantu suami meningkatkan pendapatan keluarga.

Kesiapan peran lebih penting dipersiapkan oleh perempuan karena berhubungan dengan tugas istri yang lebih banyak berada pada sektor domestik seperti mengerjakan pekerjaaan rumah tangga, mendampingi suami dan mengasuh anak. Kesiapan fisik yang sehat sama pentingnya baik bagi laki-laki atau perempuan. Hal ini terkait dengan tujuan pernikahan yaitu memiliki keturunan. Mereka yang memiliki kondisi fisik yang kurang sehat misalnya kurang subur atau memiliki riwayat penyakit degeneratif seperti diabetes mellitus, hendaknya lebih mempersiapkan kesehatan diri misalnya dengan menjalankan pola hidup sehat. Kesiapan seksual lebih penting dipersiapkan oleh perempuan. perubahan fisik janin yang begitu cepat selama masa kandungan membutuhkan keterampilan ibu yang mengandung untuk menjaga kesehatan dengan mengontrol kondisi organ reproduksi dan mengatur kecukupan asupan gizi ketika hamil sehingga kesehatan ibu dan janin bisa terjaga dengan baik.

Kesiapan spiritual lebih penting dipersiapkan oleh laki-laki. Hal ini karena seorang suami adalah imam dan pemimpin keluarga. Kesiapan sosial lebih penting dipersiapkan oleh laki-laki. Laki-laki sebagai pemimpin keluarga harus mampu mengorganisasikan keluarganya untuk bekerja sama guna mencapai tujuan keluarga. Menurut Schelegel dan Barry (1991) pada masyarakat matrilokal yang umumnya pengantin wanita membawa suami tinggal bersama keluarganya, membuat laki-laki dituntut memiliki keterampilan sosial yang baik.

Hasil analisis faktor menghasilkan faktor mengelola emosi sebagai faktor pertama yang terbentuk, mengelola emosi diperlukan karena masalah-masalah dalam pernikahan bisa menimbulkan frustrasi dan tekanan pada pasangan, terutama yang baru menikah. Kemampuan mengelola emosi akan menghindari pasangan untuk melakukan tindakan agresif maupun merusak diri sendiri, apalagi saat ini banyak terjadi kasus kekerasan dalam rumah tangga (KDRT). Pada faktor kesiapan finansial, terdapat faktor tidak merokok. Salah satu masalah keuangan rumah tangga bukan hanya pendapatan rendah tapi juga salahnya pengalokasian pendapatan. Banyak keluarga miskin yang lebih memprioritaskan belanja rokok dari pada kebutuhan gizi keluarga. Hasil survey Sosial Ekonomi Nasional (2006) 
mencatat bahwa alokasi belanja rokok pada keluarga miskin perokok menempati urutan kedua setelah beras (YLKI 2011).

Pada faktor kesiapan peran, kemampuan untuk mengambil keputusan merupakan salah satu pernyataan penting. Dalam pernikahan suami-istri harus mampu mengambil keputusan dengan bijak, misalnya keputusan penting mengenai pendidikan anak, tujuan yang ingin dicapai keluarga, maupun hal-hal kecil misalnya seorang istri harus mampu membuat keputusan mengenai barang-barang kebutuhan yang harus dibelanjakan. Kesiapan seksual berarti bahwa organ reproduksi seksual perempuan sudah matang dan sudah tepat untuk hamil. Hal ini terkait dengan tujuan menikah yaitu ingin memperoleh keturunan. Kesiapan untuk hamil tidak hanya persiapan fisik tetapi juga kesiapan mental, yang harus dipersiapkan sebelum hamil. Kondisi kesehatan seorang calon ibu, senantiasa akan berhadapan dengan gangguan, misalnya gangguan penyakit, hal tersebut akan memberikan efek samping kepada janin yang sedang dikandung. Faktor keterampilan sosial juga diperlukan, hubungan sosial paling penting dalam pernikahan tentu saja hubungan antar pasangan, dengan memiliki hubungan yang baik pasangan akan mampu bekerja sama dengan baik. Selain itu, setelah tinggal di lingkungan yang baru, pasangan harus mampu membina hubungan dengan tetangga.

Kognisi sosial juga penting untuk dimiliki. Kognisi sosial adalah mengetahui apa yang diharapkan dalam kebanyakan situasi sosial misalnya etiket dan mampu mengartikan isyarat sosial dan memahami norma yang tersirat (Goleman 2007). Salah satu cara yang bisa dilakukan untuk meningkatkan kemampuan kognisi sosial adalah melihat figur pernikahan yang bisa ditiru, Hurlock (1994) mengemukakan bahwa memiliki teladan akan mendorong dewasa muda untuk menguasai tugas-tugas perkembangannya. Faktor yang terakhir terbentuk adalah kemampuan toleransi. Menurut Erikson (1963) dewasa muda berada pada tahap intimasi melawan isolasi. Pada tahap ini individu harus membangun kepribadian yang mampu melebur dengan kepribadian orang lain agar mampu membentuk keintiman. Proses ini membutuhkan kontrol emosi dan kompromi atau toleransi yang tinggi. Jika gagal maka individu akan merasa terisolasi. Sehingga toleransi juga dibutuhkan dalam membangun hubungan pernikahan.

Rata-rata usia ingin menikah perempuan lebih tinggi daripada usia ideal, laki-laki sebaliknya usia ingin menikah justru lebih muda dibandingkan usia idealnya. Dewasa muda yang merupakan mahasiswa memiliki pendidikan yang tinggi. Pada wanita pendidikan yang tinggi akan membuka peluang untuk mengejar karir sebelum menikah, sedangkan pada laki-laki justru menjadi peluang untuk memperoleh pekerjaan yang lebih baik, sehingga lebih cepat memperoleh kesiapan finansial. Usia ingin menikah perempuan lebih muda dari pada usia ingin menikah laki-laki, salah satu penyebab hal ini terjadi karena masa pubertas perempuan lebih cepat dari laki-laki (Hurlock 1994). Perbedaan usia ini berhubungan dengan pengendalian fertilitas, wanita yang menikah lebih muda akan memiliki masa reproduksi yang lebih lama dibandingkan wanita yang menikah lebih tua (Schelegel dan Barry 1991). Semakin tinggi uang saku maka semakin tua usia ingin menikah. Perempuan yang memiliki kondisi finansial keluarga yang cukup, tidak mencari keamanan finansial dengan menikah, sedangkan yang berpendapatan rendah bisa mengharapkan memperoleh dukungan finansial dengan menikah. Bagi laki-laki, pendapatan keluarga besar akan membuat mereka berusaha lebih keras untuk mencapai standar yang sama dengan keluarganya (Thornton, 1989).

Dewasa muda laki-laki yang merupakan anak pertama memiliki usia ingin menikah yang lebih muda. Hasil penelitian ini mendukung hasil penelitian oleh Murdoch (2011). Penelitian yang berjudul "Birth Order and Age at Marriage" (Urutan Lahir dan Usia Menikah) menunjukkan rata-rata usia menikah anak sulung laki-laki lebih rendah dari pada rata-rata usia menikah anak laki-laki bukan sulung. Pada mahasiswa laki-laki yang berasal dari keluarga besar, maka ada peluang yang lebih besar untuk membangun keluarga baru dengan jumlah anak yang juga banyak. Pasangan yang memiliki keinginan memiliki anak yang banyak, akan menikah lebih muda. Mahasiswa yang sedang berpacaran memiliki usia ingin menikah lebih muda. Pengalaman berpacaran akan mengajarkan seseorang mengenai komitmen, toleransi, dan berkompromi, serta sarana mengenal pasangan dan kelurganya. Penelitian yang dilakukan oleh Karadag (2006) menghasilkan bahwa mereka yang memiliki pengalaman berpacaran akan lebih sering membicarakan isu mengenai pernikahan. Mereka yang memiliki pasangan juga lebih memiliki inisiatif untuk menikah. 
Mahasiswa laki-laki yang berasal dari keluarga miskin ingin menikah lebih tua, karena ingin memiliki kondisi ekonomi yang lebih mapan. Hal ini dikarenakan laki-laki bertanggung jawab atas kebutuhan hidup keluarga. Perempuan yang berasal dari keluarga miskin justru ingin menikah lebih cepat, karena mengharapkan adanya pegangan ekonomi yang berasal dari suami. Perempuan yang memiliki orang tua yang tidak lengkap akibat meninggal atau bercerai memiliki usia ingin menikah yang lebih tua. Pengalaman akibat perceraian akan membuat anak merasa trauma. Pengalaman hidup bersama ibu tunggal akan membuat dewasa muda perempuan mengejar karir yang mapan dahulu sebelum menikah. Hal tersebut merupakan tindakan preventif apabila mengalami kondisi yang sama seperti ibunya. (Berryman dan Waite, 1987 dalam Thornton 1989).

Pendidikan orang tua yang semakin tinggi akan membuat semakin tua usia ingin menikah dewasa muda perempuan. Pendidikan ibu yang tinggi akan memberikan gambaran kepada bahwa perempuan juga memiliki peluang untuk memperoleh pencapaian dalam pendidikan. Ibu yang berpendidikan tinggi juga memiliki pekerjaan yang lebih baik, dan akan memberikan gambaran bahwa perempuan harus bekerja dahulu sebelum menikah.

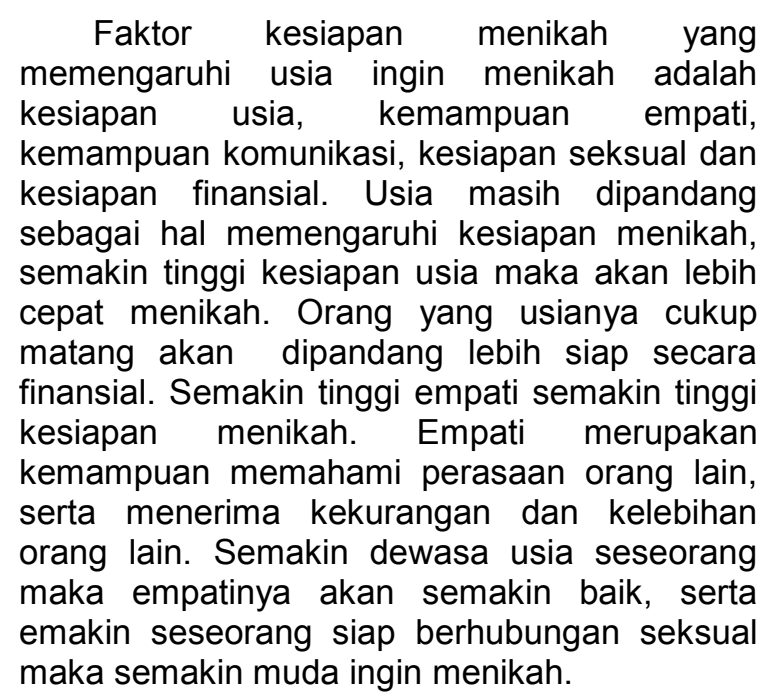

Kemampuan komunikasi berpengaruh pada usia menikah dan diperlukan dalam pernikahan. Banyak kasus pertengkaran rumah tangga terjadi hanya karena kesalahan berkomunikasi. Kesiapan usia berpengaruh negatif pada usia ingin menikah perempuan. Perempuan yang menganggap kesiapan usia sebagai faktor penting dalam pernikahan ingin menikah lebih muda, dibandingkan perempuan yang tidak terlalu mengaanggap usia sebagai salah satu kesiapan pernikahan.

\section{SIMPULAN DAN SARAN}

Faktor kesiapan menikah yang teridentifikasi dari persepsi dewasa muda terdiri atas kesiapan emosi, sosial, finansial, peran, kesiapan seksual, dan kematangan usia. Terdapat perbedaan antara kesiapan menikah bagi laki-laki dan kesiapan menikah perempuan. Faktor kesiapan menikah laki-laki adalah kesiapan finansial, kesiapan emosi, kesiapan peran, kesiapan fisik, kesiapan spiritual, dan kesiapan sosial. Faktor kesiapan menikah untuk perempuan adalah kesiapan emosi, kesiapan peran, kesiapan finansial, dan kesiapan fisik, kesiapan seksual, dan kesiapan spiritual.

Rata-rata usia ideal menikah untuk laki-laki adalah 26,31 tahun dan perempuan rata-rata 23,98 tahun. Rata-rata usia ingin menikah lakilaki adalah 26,15 tahun dan perempuan 24,24 tahun. Pada perempuan usia ingin menikah lebih tua dibandingkan usia idealnya, sedangkan pada laki-laki usia ingin menikah lebih muda dari usia idealnya. Karakteristik dewasa muda yang memengaruhi usia ingin menikah adalah jenis kelamin, uang saku, status berpacaran, dan urutan anak. Karakteristik keluarga yang memengaruhi adalah pendidikan orang tua, pendapatan per kapita, dan kelengkapan orang tua. Kesiapan menikah juga berpengaruh pada usia menikah. Semakin tinggi kesiapan usia dan kemampuan komunikasi maka semakin muda usia menikah, namun semakin tinggi kesiapan finansial dan empati maka semakin tua usia menikah.

Hasil penelitian ini diharapkan dapat dimanfaatkan bagi dewasa muda yang hendak menikah baik laki-laki maupun perempuan. Dewasa muda perlu menyiapkan emosi secara matang, terutama mengelola emosi dan empati. Hal ini bisa dilakukan dengan banyak membaca referensi buku, serta mempelajari pernikahan dari lingkungan keluarga maupun lingkungan sosial. Dewasa muda sebaiknya memiliki figur pernikahan yang bisa ditiru sehingga bisa mendapatkan gambaran mengenai masalah dalam pernikahan dan solusi untuk mengatasinya. Kesiapan peran juga penting dipersiapkan terutama perempuan. Peran perempuan lebih banyak pada sektor domestik sehingga perempuan harus belajar mengerjakan berbagai tugas dalam rumah tangga dan mengasuh anak. Kesiapan finansial harus lebih dipersiapkan oleh calon pasangan laki-laki, karena laki-laki adalah pemimpin dan pencari 
nafkah utama dalam keluarga. Sebelum menikah sebaiknya laki-laki memiliki pekerjaan tetap dan mampu memenuhi kebutuhan hidup keluarganya. Kesiapan seksual juga harus dipersiapkan lebih baik oleh perempuan, terkait dengan peran perempuan sebagai calon ibu yang akan mengandung dan melahirkan. Penelitian ini juga menyarankan pemerintah untuk membuat program pendidikan tentang pernikahan agar dewasa muda memiliki kesiapan menikah yang lebih baik.

\section{DAFTAR PUSTAKA}

[BPS] Badan Pusat Statistik. (2010). Statistik Indonesia 2010, Jakarta, ID: BPS.

Blood, M. B. (1978). Marriage ( $3^{\text {rd }}$ ed). New York, US: Free Press.

Duvall,E. M., \& Miller, B. C. (1985). Marriage and family development ( $9^{\text {th }}$ ed). New York, US: Harper and Row Publisher.

Erikson, E. H. (1963). Childhood and Society $\left(2^{\text {nd }}\right.$ ed). New York, US:Norton.

Goleman, D. (1997). Kecerdasan emosional. Jakarta, ID: PT Gramedia Pustaka Utama. Terjemahan dari: Emotional Intelligence.

Goleman, D. (2007). Social intelligence. Jakarta, ID: PT Gramedia Pustaka Utama.
Havighurst, R. J. (1972). Development task and education $\left(3^{\text {th }}\right.$ ed). New York, US: Mac.

Hurlock, E. B. (1994). Psikologi perkembangan: Suatu Pendekatan Sepanjang Rentang Kehidupan. Jakarta, ID: Erlangga. Terjemahan dari: Developmental psychology: A Life-span approach.

Karadag, S. (2006). Dating behaviour, views of marriage, and marital preparation among university student. Journal of Social Science, 16.

Murdoch, J. P. (2011). Birth order and age at marriage. British Journal of Social and Clinical Psychology, 5, 24-29.

Schelegel, A., \& Barry, H. (1991). Adolescent: An antrhopological inquary. New York, US: The Free Press.

Thornton, A. (1989). Changing attitudes towards family issues in the United States. Journal of Marriage and Family, 51, 873895.

Undang-Undang Republik Indonesia Nomor 1 Tahun 1974 tentang Perkawinan \& Kompilasi Hukum Islam. (2007). Bandung, ID: Citra Umbara Kay.

[YLKI]. Yayasan Lembaga Konsumen Indonesia. (2011). Warta Konsumen edisi 2/xxxviii. Jakarta, ID: YLKI. 